\title{
EFFECTIVENESS OF THINK PAIR SHARE AND SPONTANEOUS GROUP DISCUSSION TOWARDS PROBLEM SOLVING SKILL STUDENT OF X ACCOUNTING GRADERS SMK NEGERI 1 WONOSARI
}

\section{EFEKTIVITAS THINK PAIR SHARE DAN SPONTANEOUS GROUP DISCUSSION TERHADAP KEMAMPUAN PEMECAHAN MASALAH SISWA KELAS X AKUNTANSI SMK NEGERI 1 WONOSARI}

By:

Puji Rahayu

Accounting Education Study Program Yogyakarta State University

prahayu0609@gmail.com

\section{Ani Widayati}

Lecturer in Accounting Education Study Program Yogyakarta State University ani_widayati@uny.ac.id

\begin{abstract}
This research is aimed to know: 1) the differences of problem solving skills in students' learning with Think Pair Share and Spontaneous Group Discussion; 2) the effectiveness of the implementation of Think Pair Share and Spontaneous Group Discussion. This research is a quasi-experimental research involving 32 students of X AK1 and X AK3. Data collection technique was a tests. Data analysis techniques for testing the result of this research were normality test, homogeneity test, and hypothesis test with t-test. The results of this study show that: 1) There are no differences in problem solving skill between students with Think Pair Share and student with Spontaneous Group Discussion student of X Accounting graders SMK Negeri 1 Wonosari. It proved by post-test on hypothesis test with the signification in the result of independent sample $t$-test is greater than $\alpha=0.05(0,475>0,05)$ and $t$ count $<t$ table $(0,719$ $<2,000)$. 2)There are no differences in effectiveness between students with Think Pair and student with Spontaneous Group Discussion student of X Accounting graders SMK Negeri 1 Wonosari. It proved by independent samples t-test for gain score is greater than $\alpha=0.05(0.786$ $>0.05)$ and $t$ count $<\mathrm{t}$ table $(0,272<2,000)$.
\end{abstract}

Keywords: Introduction to Accounting learning, TPS, SGD, Problem Solving Skill

\section{Abstrak}

Penelitian ini bertujuan untuk mengetahui: 1) perbedaan kemampuan pemecahan masalah di dalam pembelajaran siswa dengan Think Pair Share dan Spontaneous Group Discussion; 2) efektivitas dari implementasi Think Pair Share dan Spontaneous Group Discussion. Penelitian ini merupakan penelitian eksperimen semu dengan melibatkan 32 siswa dari kelas X AK1 dan X AK3. Teknik pengumpulan data menggunakan tes. Teknik analisis data untuk pengujian hasil penelitian menggunakan uji normalitas, uji homogenitas, dan uji hipotesis dengan uji-t. Hasil penelitian menunjukkan bahwa: 1) Tidak ada perbedaan keterampilan pemecahan masalah antara siswa yang menggunakan Think Pair Share dan siswa yang menggunakan Spontaneous Group Discussion pada siswa kelas X Akuntansi SMK 
Negeri 1 Wonosari. Hal ini dibuktikan dengan uji hipotesis post-test, dengan hasil uji Independent Sample t-Test nilai signifikansi lebih besar dari $\alpha=0,05(0,475>0,05)$ dan $t$ hitung $<t$ tabel $(0,719<2.000)$. 2) Tidak ada perbedaan efektivitas antara siswa yang menggunakan Think Pair Share dan siswa yang menggunakan Spontaneous Group Discussion pada siswa kelas X Akuntansi SMK Negeri 1 Wonosari. Hal ini dibuktikan dengan uji hipotesis gain score, dengan hasil uji Independent Sample t-Test nilai signifikansi lebih besar dari $\alpha=$ $0,05(0,786>0,05)$ dan $t$ hitung $<$ t tabel $(0,272<2.000)$.

\section{Kata Kunci: Pembelajaran Akuntansi Dasar, TPS, SGD, Kemampuan Pemecahan Masalah}

\section{INTRODUCTION}

The development of information and communication technologies (ICTs) run very fast, inline with changing in economic development. Development in various disciplines of science was intensively carried out. Education, especially Vocational High Schools (SMK), must be able to take advantage of the development of information technology to remain relevant in demands of the Industrial Revolution 4.0 era. This is a challenge for Vocational High Schools (SMK) as one of the educational institutions that conduct accounting programs. Vocational high schools certainly need to be prepared to produce students who are able to respond to these global challenges.

Accounting learning is expected to deliver students to fulfill cognitive, affective, and psychomotor abilities. This becomes very important for teachers and students in creating a learning atmosphere and learning process to answer these global challenges. According to Sanjaya (2016: 2) education should not override the learning process (education was not solely trying to achieve learning outcomes) so focus of education is how to obtain the results or learning processes.

The ability that is needed by students to face global challenges in the 2013 revised edition curriculum, consist of : 1) learning and innovation skills which include critical thinking, being able to solve problems, creative and innovative, being able to communicate and collaborate; 2) skills in using media, technology, information and communication (ICT); 3) ability to live life and pursue career, including adaptability, flexibility, initiative, being able to develop themselves, having social and cultural abilities, being productive, trustworthy, having leadership, and responsibility.

One of the abilities needed by students to face global challenges is problem solving skills. Problem solving is defined as a process, used to obtain a best answer to an unknown, or a decision subject to some constraints (Mourtos, 2004). This can be interpreted that problem solving is a process, which is used to obtain the best answer for an unknown or a decision subject for several constraints. Problem solving skills need to be mastered by students, especially vocational high school students, as a provision in facing real problems in everyday life and the world work. This is in line with what was revealed by Nurdan \& Çağda (2017) it is a widespread view that problem-solving skills help individuals to overcome the problems easily in their daily lives. An individual with problem-solving skills is a self-confident, creative and independent thinker.

Atmosphere and process of learning will be created well, if the teacher use variative learning models but unfortunately there are still many teachers at SMK Negeri 1 Wonosari who use conventional learning models in delivering introduction to accounting material. This causes many students to lose focus and enthusiasm in receiving material. From the results of observations made by researchers at SMK Negeri 1 Wonosari this even began to occur when learning activities lasted for 2 hours. Bored and sleepiness are some of the 
student reason's being less energetic. Introduction to accounting itself in class $\mathrm{X}$ of accounting graders SMK Negeri 1 Wonosari in one meeting there are 5 hours of lessons or $5 \times 45$ minutes. Of course this is one of the problems faced by both teachers and students in introduction to accounting learning.

According to the observations that have been done in introduction to accounting formative test of class X AK1 and $\mathrm{X}$ AK2 which present the case study, 15 of 32 students X AK1 and 22 of 32 students of X AK2 only got slightly score above minimum criteria of mastery learning. This shows that the level of problem solving in SMK Negeri 1 Wonosari students is still low. From the Guided Field Practice activities conducted by researchers in November 2018 on accounting to accounting subjects, it can be seen that students tend to prefer learning models using media rather than lectures. They will be more enthusiastic when learning activities are carried out actively which involves teachers, students, and learning media to help students better understand the material being taught. In addition, use various learning models greatly helps students to avoid boredom and increase enthusiasm in learning.

Each of learning models that have been developed by various experts have various advantages. The learning model that is often used is the cooperative learning model. Some models include Think Pair Share (TPS) and Spontaneous Group Discussion (SGD). Think Pair Share (TPS) and Spontaneous Group Discussion (SGD) are types of cooperative learning models. The cooperative learning model is based on the notion of constructivism, a model that expects students to build their own knowledge.

Cooperative learning type Think Pair Share (TPS) according to Huda (2015: 136137) allows students to work with other people. Think Pair Share (TPS) is able to optimize student participation, to provide at least eight times more opportunities for students to show participation, and can also be applied to all subjects and various grade levels.

Furthermore, cooperative learning type Spontaneous Group Discussion (SGD) is a learning model in which is done spontaneously. This is in line with what was revealed by Huda (2015: 129) this learning is a method of group discussion that was not planned beforehand, but carried out spontaneously and simply. The steps of cooperative learning type Spontaneous Group Discussion (SGD) consist of: asking students to group, students discuss something, the teacher calls groups one by one, and students present the results of the discussion in front of the class.

The application of various learning models needs to be done in schools. One of them is in accounting subjects at SMK. Both learning models are able to make students understand the material independently and together with friends. Students will learn the material by themselves then will join the group to express their opinions. The opinions of each of these students are then discussed together so that they will get the most appropriate problem solving. These two learning models also give all students the opportunity to express their opinions so that each individual is able to improve their problem solving skills.

Based on research conducted by Rizky Cahyaningtyas (2017), she found that Think Pair Share learning method is more effective than expository method toward creative thinking abilities student of $\mathrm{X}$ graders MAN Yogyakarta 2. Based on the independent sample t-test, the significance value was 0.012 , it means that saintific approach with think pair share cooperative method is more effective than expository method. Next, the average score of mathematical creative thinking abilities posttest of the experiment class reached 31.96 meanwhile the control class reached 28.93. 
In addition, in a study compiled by Ratih Damayanti (2013), she found that Spontaneous Group Discussion learning model can increase student learning activities in mathematics subject. This can be seen from: 1) Activities of students in asking or expressing opinions before the action is carried out $13.04 \%$, round $\mathrm{I}$ is $39.1 \%$ and round II is $65.22 \%, 2$ ) Activity of students in solving problems before action is taken $17.4 \%$, round $\mathrm{I} 43.5 \%$ and round II $73.91 \%, 3$ ) Activity of students in responding to friends' ideas before action is taken $8.7 \%$, round I is $30.43 \%$ and round II is $52.8 \%$. From the foregoing description it gives hope that Think Pair Share (TPS) and Spontaneous Group Discussion (SGD) learning models are able to overcome this problem. Based on the background above, researcher is interested in studying " Effectiveness Of Think Pair Share and Spontaneous Group Discussion Towards Problem Solving Skill Students of X Accounting Graders SMK Negeri 1 Wonosari”

\section{RESEARCH METHOD}

\section{Types of Research}

This type of research is quasiexperimental research. Quasi-experiments are carried out to obtain information from experiments that do not allow for control of all external variables that affect the conduct of experiments (Sugiyono, 2016).

\section{Research Design}

This study used a pretest-posttest nonequivalent group design. Both experimental groups were selected randomly and pretest and posttest were held for each group.

Table 1. Experimental Design Draft Experimental Class $1 \mathrm{O}_{1} \mathrm{X} \mathrm{O}_{3}$

Experimental Class $\mathrm{O}_{2} \mathrm{X} \mathrm{O}_{4}$

\section{Place and Time}

This research was held at SMK Negeri 1 Wonosari in Veteran Street, Wonosari,
Gunungkidul, Daerah Istimewa Yogyakarta in X Accounting graders of SMK Negeri 1 Wonosari academic year of 2018/2019. This research was conducted on May of 2019.

\section{Population and Sample}

The population in this study were all students of $X$ Accounting graders SMK Negeri 1 Wonosari in the academic year $2018 / 2019$ as many as 128 students. The subjects in this study were student of $\mathrm{X}$ AKL 1 and $X$ AKL 3 using random sampling.

\section{Data Collecting Technique}

In this study, data collection technique was test. Pretest and posttest data were used to obtain data on students' problem solving skill before and after being treated. Pretest is done before the treatment is given while the posttest is given after students are treated. The treatment referred to here is accounting learning using Think Pair Share (TPS) and accounting learning using Spontaneous Group Discussion (SGD).

\section{Research Instrument}

Instruments in this research are used to measure problem solving skills, namely pretest and posttest. The pretest and posttest questions are made in the form of 4 questions. The research instrument was made based on the material in the $X$ accounting graders on adjusting journals. The aspects measured in this study are the ability of students to understand problems, devise a plan, the ability of students to solve problems according to plan, and students' ability to looking back.

\section{Test and Analysis of Research Instrument}

The validity used in this study is content validity. To get content validity criteria, the instrument is consulted with experts (expert judgment) to be examined whether the instrument has represented what will be measured. The Judgment Experts in this 
study are an expert lecturer in accounting education at Yogyakarta State University and introduction to accounting teacher at SMK N 1 Wonosari. After an evaluation by the expert team, the researcher made a revision based on input from the expert team.

\section{Data Analysis Techniques}

a. Descriptive Analysis

Descriptive analysis aims to determine the general picture of student achievement based on pretest and posttest data on students 'problem solving skills. The statistical technique used to describe research data includes the mean, standard deviation, variance, minimum value, and maximum value. Calculation of descriptive analysis was carried out with the help of IBM SPSS Statistics 23 program.

b. Data Analysis

1) Prerequisite Test for Analysis

a) Normality Testing

The normality test aims to find out the data from each Think Pair Share (TPS) class and Spontaneous Group Discussion (SGD) class that is normally distributed or not. If the data comes from a population that is normally distributed, the data can be used in parametric statistics (inferential statistics). Normality testing in this study used Kolmogorov Smirnov significance level of 0.05 .

b) Homogeneity testing

Homogeneity testing was used to determine whether the two groups had homogeneous variances or not. The homogenity testing in this study uses Levene's with the help of the IBM SPSS Statistics 23 program. Test decisions and conclusions are taken at the 0.05 significance level. In this case Ho will be accepted if the significance value is more than 0.05 .

c. Hypothesis Testing

Hypothesis testing in this study using the Independent sample $t$ test. Independent sample $t$ test was used to analyze the differences in effectiveness of Think Pair Share and Spontaneous Group Discussion in terms of problem solving skill. Data analysis regarding the improvement of problem solving skill is calculated using the Gain Score. Gain score or also called an increase or difference in score is the cycle value after treatment minus the cycle value before treatment. The results of data analysis with Gain Score are presented in the form of percentages so that they can show the achievement of improvement by paying attention to their initial abilities.

\section{RESULT AND DISCUSSION Descriptive Analysis}

Scores of pretest value in the first experimental class is 61,28 . Whereas the average scores of posttest in the first experimental class is 86,34 . In this case, it can be seen that the average scores of introduction to accounting's problems solving skill with Think Pair Share (TPS) learning model has increased. The increase in the average score of introduction to accounting's problems solving skill achieved by the first experimental class is 25,06 . In addition, scores of pretest score in second experimental class is 67,03. Whereas the average scores of posttest in the second experimental class is 88,62 . In this case it can be seen that the average scores of introduction to accounting's problems solving skill with Spontaneous Group Discussion (SGD) learning model has increased. The increase in the average score of introduction to accounting's problems solving skill achieved by the second experimental class is 21,59 . 
Table 2. Data Description of Pretest and Posttest

\begin{tabular}{|c|c|c|c|c|}
\hline \multirow{2}{*}{ Data } & \multicolumn{2}{|c|}{$\begin{array}{c}\text { Experimental } \\
\text { Class 1 }\end{array}$} & \multicolumn{2}{|c|}{$\begin{array}{c}\text { Experimental } \\
\text { Class 2 }\end{array}$} \\
\cline { 2 - 5 } & $\begin{array}{c}\text { Pre- } \\
\text { Test }\end{array}$ & $\begin{array}{c}\text { Post- } \\
\text { Test }\end{array}$ & $\begin{array}{c}\text { Pre- } \\
\text { Test }\end{array}$ & $\begin{array}{c}\text { Post- } \\
\text { Test }\end{array}$ \\
\hline Min. & 34 & 70 & 47 & 77 \\
\hline Max. & 84 & 97 & 86 & 99 \\
\hline Mean & 61,28 & 86,34 & 67,03 & 88,62 \\
\hline $\begin{array}{l}\text { Standard } \\
\text { Deviation }\end{array}$ & 12,493 & 7,443 & 9,682 & 6,592 \\
\hline Variance & 156,080 & 55,394 & 93,749 & $\begin{array}{c}43,45 \\
8\end{array}$ \\
\hline
\end{tabular}

Although average scores of pretest of problem solving skill in the second experimental class was higher than the first experimental class, but the increase in the average scores of introduction to accounting's problems solving skill in the first experimental class was greater when compared to the second experimental class Increasing introduction to accounting's problems solving skill in students can also be seen through the percentage of each aspect of introduction to accounting's problems solving skills in students, which is presented in the following Table 3 .

Table 3. Percentage of Problem Solving Skill in Each Aspect

\begin{tabular}{|l|l|l|l|l|l|}
\hline \multirow{2}{*}{ No. } & \multirow{2}{*}{ Aspect } & \multicolumn{2}{|c|}{$\begin{array}{c}\text { Experimental } \\
\text { Class 1 (TPS) }\end{array}$} & \multicolumn{2}{c|}{$\begin{array}{l}\text { Experimental } \\
\text { Class 2 (SGD) }\end{array}$} \\
\cline { 3 - 6 } & $\begin{array}{l}\text { Pre- } \\
\text { Test }\end{array}$ & Post-Test & $\begin{array}{l}\text { Pre- } \\
\text { Test }\end{array}$ & $\begin{array}{l}\text { Post- } \\
\text { Test }\end{array}$ \\
\hline 1. & $\begin{array}{l}\text { Understand the } \\
\text { problem }\end{array}$ & $90 \%$ & $96 \%$ & $86 \%$ & $92 \%$ \\
\hline 2. & Devise plan & $60 \%$ & $91 \%$ & $65 \%$ & $88 \%$ \\
\hline 3. & Carry out the plan & $48 \%$ & $79 \%$ & $55 \%$ & $84 \%$ \\
\hline 4. & Look back & $34 \%$ & $72 \%$ & $58 \%$ & $84 \%$ \\
\hline Source : Primary Data & & & & \\
\hline
\end{tabular}

Based on the table above, it is known that the percentage of each aspect of problem solving skill in the first experimental class and the second experimental class has increased.
Prerequisite for Analysis Testing

a. Normality Testing

1) Testing for Pretest Scores

Table 4. Normality Testing Results for Pre-test Scores

\begin{tabular}{|c|c|c|}
\hline Kolmogorov-Smirnov Normality Testing \\
\hline Class & $\begin{array}{c}\text { Asymp. } \\
\text { Sig. } \\
\text { (2-tailed) }\end{array}$ & Result \\
\hline $\begin{array}{c}\text { Experimental Class } \\
\text { 1 (TPS) }\end{array}$ & 0,200 & Normal \\
\hline $\begin{array}{c}\text { Experimental Class } \\
\text { 2 (SGD) }\end{array}$ & 0,200 & Normal \\
\hline
\end{tabular}

From Table 4, it can be seen that the significance value of the pretest scores in the experimental class 1 and experimental class 2 exceeds the specified significance level of 0.05 . This means that scores of pretest in introduction to accounting problem solving skills are normally distributed.

2) Testing for Post-test Scores

Table 5. Normality Testing Results for Post-test Scores

Kolmogorov-Smirnov Normality Testing

\begin{tabular}{|l|c|l|}
\hline \multicolumn{1}{|c|}{ Class } & $\begin{array}{c}\text { Asymp. } \\
\text { Sig. } \\
\text { (2-tailed) }\end{array}$ & Result \\
\hline $\begin{array}{l}\text { Experimental } \\
\text { Class 1 (TPS) }\end{array}$ & 0,117 & Normal \\
\hline $\begin{array}{l}\text { Experimental } \\
\text { Class 2 (SGD) }\end{array}$ & 0,105 & Normal \\
\hline
\end{tabular}

The significance value of the pretest scores in the experimental class 1 and experimental class 2 exceeds the specified significance level of 0.05 . This means that scores of post-test in introduction to accounting's problem solving skill are normally distributed. 


\section{Homogenity Testing}

The significance value scores of pretest and posttest on problem solving skill is $0.514>0.05$, so it can be concluded that the variant of the posttest of experimental class 1 and experimental class 2 are homogeneous or similar.

Table 6. Homogeneity Testing Results for Posttest Scores

\begin{tabular}{|c|c|c|}
\hline Data & Significance & Result \\
\hline $\begin{array}{c}\text { Problem } \\
\text { Solving Skill }\end{array}$ & 0,514 & Homogen \\
\hline
\end{tabular}

\section{Hypothesis Testing}

a. Hypothesis test for experimental class 1 (Think Pair Share) and experimental class 2 (Spontaneous Group Discussion) Pretest

The hypothesis used for the T test for the pre-test scores of problem solving skill are as follows:

Ho : there is no difference in problem solving skill in students' learning with Think Pair Share (TPS) and Spontaneous Group Discussion (SGD)

$\mathrm{Ha}$ : there is difference in problem solving skill in students' learning with Think Pair Share (TPS) and Spontaneous Group Discussion (SGD).

Table 7. T-Test Results for Pre-Test Scores

\begin{tabular}{|c|c|c|c|}
\hline Variable & $\begin{array}{c}\text { Experimental } \\
\text { Class }\end{array}$ & Mean & Sig. \\
\hline Problem & $\begin{array}{c}\text { Think Pair } \\
\text { Share }\end{array}$ & 61,28 & \\
\cline { 2 - 3 } $\begin{array}{c}\text { Solving } \\
\text { Skill }\end{array}$ & $\begin{array}{c}\text { Spontenous } \\
\text { Group } \\
\text { Discussion }\end{array}$ & 67,03 & \\
& \multicolumn{2}{|c|}{6,051} \\
\hline
\end{tabular}

The significance value of pretest scores on the experimental class 1 and experimental class 2 was $0.051>0,05$ and $t$ count $<t$ table $(1,995<2,000)$. This indicates that Ho is accepted. In other words, there is no significant difference in problem solving skill in students' learning with Think Pair Share (TPS) and Spontaneous Group Discussion (SGD), so the initial ability of the two groups in the aspect of problem solving skill is same.

b. Hypothesis Test for Experimental Class 1 (Think Pair Share) and Experimental Class 2 (Spontaneous Group Discussion) Post-Test

The hypothesis used for T-test for posttest scores of problem solving skill are as follows:

Ho : there is no difference in problem solving skill in students' learning with Think Pair Share (TPS) and Spontaneous Group Discussion (SGD)

$\mathrm{Ha}$ : there is difference in problem solving skill in students' learning with Think Pair Share (TPS) and Spontaneous Group Discussion (SGD)

Table 8. T-Test Result for Post-Test Scores

\begin{tabular}{|c|c|c|c|}
\hline Variable & Group & Mean & Sig. \\
\hline Problem & $\begin{array}{c}\text { Think Pair } \\
\text { Share }\end{array}$ & 86,34 & \\
$\begin{array}{c}\text { Solving } \\
\text { Skill }\end{array}$ & $\begin{array}{c}\text { Spontenous } \\
\text { Group } \\
\text { Discussion }\end{array}$ & 87,62 & \\
& & \\
& &
\end{tabular}

The significance value posttest scores in the experimental class 1 and experimental class 2 was $0.475>0.05$. and $t$ count $<\mathrm{t}$ table $(0,719<2,000)$. This indicates that Ho is accepted. In other words, there is no significant difference in problem solving skill in students' learning with Think Pair Share (TPS) and Spontaneous Group Discussion (SGD), then the final skill of both groups in the aspect of problem solving skill was the same.

c. Hypothesis test for N-Gain Score Experimental Class 1 (Think Pair Share) and Experimental Class 2 (Spontaneous Group Discussion) 
We can see in gain score t-test, categorization of the interpretation of the effectiveness of the $\mathrm{N}-$ Gain value (\%). The interpretation in question can be guided by the table below:

Table 9. Categories of Interpretation of N-Gain Score Effectiveness

\begin{tabular}{|c|c|}
\hline Presentase (\%) & Interpretation \\
\hline$<40$ & Ineffective \\
\hline $40-55$ & Less effective \\
\hline $56-75$ & Effective enough \\
\hline$>76$ & Effective \\
\hline
\end{tabular}

The results of t-test gain score are summarized in the table below:

Table 10. Data Description of N-Gain Score

\begin{tabular}{|l|c|c|c|c|}
\hline Class & N & Mean & $\begin{array}{c}\text { Std. } \\
\text { Deviation }\end{array}$ & $\begin{array}{c}\text { Std. } \\
\text { Error } \\
\text { Mean }\end{array}$ \\
\hline $\begin{array}{l}\text { Experi } \\
\text { mental } \\
\text { Class 1 }\end{array}$ & 32 & 62,8394 & 20,91277 & 3,69689 \\
\hline $\begin{array}{l}\text { Experi } \\
\text { mental } \\
\text { Class 2 }\end{array}$ & 29 & 61,4629 & 18,31548 & 3,40110 \\
\hline
\end{tabular}

Based on table 10, output group statistics above shows that the average scores (mean) of N-Gain Score for experimental class 1 is 62.8394 or rounded to $62.9 \%$. Based on the table of interpretation categories the effectiveness of $\mathrm{N}$-Gain value (\%) above, it can be concluded that use Think Pair Share learning models is effective enough to improve problem solving skills students of $X$ accounting graders SMK N 1 Wonosari.

Furthermore, it is known that the average scores (mean) of N-Gain Score for experimental class 2 is 61.4629 or rounded to $61.5 \%$. Based on the table of interpretation categories of the effectiveness of the $\mathrm{N}$-Gain value $(\%)$ above, it can be concluded that use
Spontaneous Group Discussion learning model is effective enough to improve problem solving skill student of $\mathrm{X}$ accounting graders SMK N 1 Wonosari.

Based on result of interpretation categories of the effectiveness of the $\mathrm{N}$ Gain value (\%) each learning models, it can be concluded that there is no difference in effectiveness between student with Think Pair Share and students with Spontenous Group Discussion to improve problem solving skill student of $\mathrm{X}$ accounting graders SMK N 1 Wonosari.

Table 11. T-test Result for N-Gain Score

\begin{tabular}{|c|c|c|}
\hline N-Gain Persen & Sig. & $\begin{array}{l}\text { Sig (2- } \\
\text { tailed) }\end{array}$ \\
\hline $\begin{array}{c}\text { Equal Variances } \\
\text { Assumed }\end{array}$ & 0,617 & 0,786 \\
\hline
\end{tabular}

Based on table 11. it is known that the significance value ( $\mathrm{Sig}$ ) (2-tailed) is $0.786>0.05$ and $t$ count $<\mathrm{t}$ table $(0,272$ $<2,000)$.this indicate that $\mathrm{Ho}$ is accepted. In other words, there is no significant difference in effectiveness of the implementation of Think Pair Share and Spontaneous Group Discussion.

\section{Discussion}

1. The Increase of Problem Solving Skill in Introduction to Accounting of Experimental Class 1 and Experimental Class 2

Before being given treatment, pre-test for experimental class 1 and experimental class 2 must be done to find out whether there are no differences in the ability of the two classes. To find out the initial ability of both classes can be seen from the average pre-test and the similarity test of pre-test. From the data obtained that the average scores of pretest in the experimental class 1 is 61.28 and experimental class 2 is 67.03 .

In other hand the average scores of post-test in the experimental class 1 is 86,34 and experimental class 2 is 88,62 . 
To find out the results of the group similarity test, the normality test and homogenity test were conducted on pretest scores with help of the SPSS statistical program 23. The normality test results showed that both classes were normally distributed and the homogeneity test results showed the same variance. After it is known that the class is normally distributed and has the same variance, a group similarity test can be performed with an independent sample t-test (equal variance assumed). From the results of the analysis it was found that two classes had the same initial abilities. This is evidenced from the results of calculations, namely that Sig. (2-tailed) greater than $\alpha=0.05$, Sig. $0,051>0,05$ and $t$ count $<\mathrm{t}$ table $(1,995$ $<2,000)$, it can be concluded that there is no significant difference of problem solving skill in students' learning with Think Pair Share and Spontaneous Group Discussion. This means the initial state of students in experimental class 1 and experimental class 2 before being treated, has the same ability.

After pre-test, then proceed with giving treatment by applying Think Pair Share learning model to experimental class 1 and experimental class 2 by applying Spontaneous Group Discussion learning model. After administering the treatment by applying different learning models between experimental class 1 and the experimental class 2, students conducted a post-test to determine the extent to which the material discussed could be harmonized and absorbed by students. Post-tests are also used to determine the increase of problem solving skill in students.

The increased of introduction to accounting's problem solving skill in students can also be seen through the percentage of each aspect of introduction to accounting problem solving skill on students. Based on the percentage of problem solving skills for each aspect, the first experimental class and the second experimental class increased. However, the increased of average in the percentage of aspects of problem solving skills in experimental class 1 was higher than the average increase in the aspect of problem solving skills in experimental class 2 . In terms of understanding the problem the increase in experimental class 1 was $6 \%$ while in experimental class 2 was $6 \%$, aspects of devise a plan experimental class 1 were $31 \%$ and experimental class 2 was $23 \%$. In the aspect of carry out the plan, experimental class 1 has increased by $31 \%$, while in experimental class 2 is $23 \%$. The last aspect was look back experimental class 1 has increased by $38 \%$ and experimental class 2 by $26 \%$.

These results indicated that problem solving in both of experimental class with Think Pair Share and Spontaneous Group Discussion learning models have increased in each aspects. Think Pair Share learning model provide an opportunity for students to solve the problem of adjusting journals given individually or in groups. For example at the think stage, students have the opportunity to think and write ideas individually.

Students seem to be serious in making small notes containing ideas and things that have not been understood about the problem of adjusting journals given at the stage of student orientation to the problem. Before making a small note, students first read and think about the problem, so it helps students to understand and plan the resolution of the adjustment journal issue given. This is in line with the opinion of Wiederhold (Martinis \& Bansu, 2009) which states that making small notes can improve students' thinking skills when analyzing a given problem.

In the pair stage, students have the opportunity to discuss in order to solve the problems given with their chairmate. 
Students have the opportunity to discuss small notes containing ideas about solving problems with their peers. This can help students determine the most appropriate problem solving in accordance with the results of discussions with their peers. The figure of pair stage which shows how student discussed their ideas with chairmate will be displayed in next page.

They then convey these ideas to other students in share stage. Each group was asked to share the results of the discussion they had obtained with a larger group through a presentation in front of the class. The presentation is done until a quarter of the groups have the opportunity to make a presentation. This stage also allows students to get advice and input from other students. This will make it easier for students to understand and solve problems. In other hands, this stage can help student to gain more confidences.

Spontaneous group discussion is learning model that carried out in a discussion spontaneously without any previous notice to students. The purpose of this model is increasing problem solving skills students related to subject matter and faced problems without any prior preparation or spontaneously.

Spontaneous Group Discussion provides an opportunity for students to solve problem of adjusting journals with their groups. They can analyze and develop a problems they got in groups. If students can sit in groups, it is easier to ask them at different times during the delivery of learning activity or presentations, to discuss what the purpose of the thing is, why something works, or how to solve a problem. It takes students to do these tasks can vary from just a few minutes to a full lesson session (Slavin, 2016).

Groups can share their opinions in front of the class. They can get advices and inputs from other students. This will make it easier for students to understand and solve the problems. The figure of student discussed with their group will be displayed in next page.

2. Think Pair Share Learning Model is as Effective as Spontaneous Group Discussion Learning Model for Increasing Problem Solving Skill

Problem solving skill of students in experimental class 1 by applying Think Pair Share learning model was obtained by the average of pre-test scores is 61.28 and the average of post-test scores is 86.34, whereas in the experimental class 2 that applying Spontaneous Group Discussion learning model obtained an average of pre-test scores is 67.03 and the average of post-test scores is 88.62 . Based on the results of calculations with an independent sample t-test it is known that the average increase in experimental class 1 is equal to 25.06 and in the experimental class 2 is 21.59. Sig. (2tailed) of $0.786>0.05$ and $t$ count $<\mathrm{t}$ table $(0,272<2,000)$, so it can be stated that there is no significant difference between problem solving skill in students' learning with Think Pair Share and Spontaneous Group Discussion.

Furthermore, it is known that the average value (mean) of N-Gain Persen for experimental class 1 is 62.8394 or rounded to $62.9 \%$. Based on the table of categories of interpretation of the effectiveness of the N-Gain value (\%) above, it can be concluded that both of Think Pair Share and Spontaneous Group Discussion effective to improve accounting skills in student of $\mathrm{X}$ accounting graders SMK N 1 Wonosari.

In addition to supported the results of data analysis and explanation, the effectiveness of problem-based adjustment journal learning using TPS learning models in terms of problem solving skills is also supported by previous studies even though they are applied to different subjects. For 
example research conducted by Fadiah Khairina (2008) on students of VII graders SMP Negeri 1 Wonosari which showed that problem-based learning in mathematics with Think Pair Share could improve students' problem solving skill. In addition, research conducted by Dini Kinanti Fardah (2010) on students of VIII C graders SMP Negeri 1 Bantul gave the conclusion that Think Pair Share (TPS) learning model can improve students' mathematical problem solving skill.

Thus, based on the results of data analysis, previous explanations, and the relevant research results, it can be concluded that problem-based introduction to accounting learning using Think-Pair-Share (TPS) learning model is effective enough in terms of problem solving skill. The average value (mean) N-Gain Score for experimental class 2 is 61.4629 or rounded to $61.5 \%$. Based on the table of categories of interpretation the effectiveness of the $\mathrm{N}$ Gain value (\%) above, it can be concluded that used Spontaneous Group Discussion learning model is effective enough to improve introduction to accounting skills in student of $\mathrm{X}$ accounting graders SMK N 1 Wonosari. This is in line with the research conducted by Nurhidayah (2012) in students of VIII graders SMP 2 Tanete Rilau which states that the application of Spontaneous Group Discussion learning model is effective in improving mathematics learning outcomes. This is indicated by the apparent increase from the average pretest of 32.16 which increases at the average posttest value of 45.67. Based on result of interpretation categories of the effectiveness of the NGain value (\%) each learning models, it can be concluded that Think Pair Share $(62,9 \%)$ and Spontenous Group Discussion $(61,5)$ are effective enough to improve problem solving skills.
CONCLUSIONS AND SUGGESTIONS Conclusions

Based on the discussion that has been described previously, then obtained following conclusions:

a. There is no difference of problem solving skill in students' learning with Think Pair Share and Spontaneous Group Discussion of $\mathrm{X}$ Accounting graders SMK Negeri 1 Wonosari. This is evidenced by results of research based on independent samples t-test, t-test posttest score states that Sig. $0.475>0.05$ and $t$ count $<t$ table $(0,719<2,000)$, then Ho is accepted and Ha is rejected. Ho is "There are no differences of problem solving skill in students' learning with Think Pair Share and Spontaneous Group Discussion"

b. There is no difference in effectiveness of the implementation of Think Pair and Spontaneous Group Discussion in introduction to accounting of student of $\mathrm{X}$ Accounting graders SMK Negeri 1 Wonosari. This is evidenced by results of research based on independent samples t-test for gain score that Sig. $0.786>0.05$ and $t$ count $<t$ table $(0,272<2,000)$, then Ho is accepted and $\mathrm{Ha}$ is rejected. Ho is "There are no differences in efectiveness of implementation of Think Pair and Spontaneous Group Discussion in introduction to accounting of student of $\mathrm{X}$ Accounting graders SMK Negeri 1 Wonosari”.

\section{Suggestion}

Based on the results of the research discussion and the conclusion of the research above, it can be given some suggestions as follows:

a. For Accounting Teachers

Implementation of introduction to accounting problem-based learning model Think-Pair- Share (TPS) and Spontaneous Group Discussion (SGD) require a relatively longer time. So, when teach an accounting material using a learning model the teacher should be 
able to manage time as well as possible so that the results obtained are more optimal.

b. For Other Researchers

1) If other researchers apply accountingbased learning problems using ThinkPair-Share (TPS) and Spontaneous Group Discussion (SGD) learning models in terms of skill other than accounting problem solving, as well as on material

2) Other than adjusting journals, researchers should not only evaluate the final results, but also evaluate the development of student abilities from time to time.

3) If other researchers apply accounting problem based learning other cooperative learning models, It is recommended to give emphasis to students using more varied learning resources besides textbooks.

\section{REFERENCES}

Arends, R.I. \& Kilcher, A. (2010). Teaching for Students Learning: Becoming an accomplished Teacher. New York: Routledge.

Arikunto, S., Suhardjono, Supardi. (2016). Penelitian Tindakan Kelas. Jakarta: PT Bumi Aksara

Bransford, J.D \& Stein, B.S. (1984). The Ideal Problem Solver. New York: W. H. Freeman and Company.

Cahyani, H. \& Setyawati, R.W. (2016). Pentingnya Peningkatan Kemampuan Pemecahan Masalah melalui PBL untuk Mempersiapkan Generasi Unggul Menghadapi MEA. Semarang: Universitas Negeri Semarang

Cahyaningtyas, Rizky (2017). Keefektifan Pendekatan Saintifik Dengan Metode Pembelajaran Kooperatif Tipe Think Pair Share (TPS) Ditinjau Dari
Kemampuan Berpikir Kreatif Matematis Peserta Didik MAN Yogyakarta 2 Kelas X. Skripsi. Yogyakarta: Universitas Negeri Yogyakarta.

Chris, Watkins et al. (2002). Effective Learning. London: Institue of Education University of London.

Damayanti, Ratih (2013). Peningkatan Aktivitas Belajar Matematika Dengan Metode Spontaneous Group Discussion. Skripsi. Yogyakarta: Universitas Negeri Yogyakarta

Daryanto. (2014). Pendekatan Pembelajaran Saintifik Kuirkulum 2013. Yogyakarta: Gava Media.

Docktor, J.L., Strand, N.E., Mestre, J.P., et.al. (2015) Conceptual Problem Solving In High School Physics. Physical Review Special TopicsPhysics Education Research,11, 2.

Fograty \& Robin. (1996). Think Pair Share. Taken from www.Browardk12.fl.us/Ci/Whatsne w/strategies_and_such_/strategies/thi nkpairshare on November, 1st 2018.

Gray, Alex. (2016). The 10 skills you need to thrive in the Fourth Industrial Revolution. Taken from https://www.weforum.org/agenda/201 6/01/the-10-skills-you-need-to-thrivein-the-fourth-industrial-revolution/ on November, 1st 2018

Haynes, S.N., Richard, D.C.S., Kubany,E.S. (1995). Content Validity in Psychological Assessment: A Functional Approach to Concepts and Methods. Psychological Assessment, 7,5.

Huda, Miftahul. (2015). Cooperative Learning, Metode, Teknik, Struktural 
dan Model Penerapan. Yogyakarta: Pustaka Pelajar.

Jonassen, D.H. (2011). Learning to Solve Problems. New York: Routledge

Klingler, K.L (2012). Mathematic Strategies for Teaching Problem Solving: The Influence of Teaching Mathematical Problem Solving Strategies on Students' Attitudes in Middle School. Thesis. Florida: University of Central Florida

Majid, Abdul. (2017). Strategi Pembelajaran. Bandung: PT Remaja Rosdakarya.

Mc.Taggart \& Kemmis S. (1990). The Action Research Planner. Melbourne: Deakin University.

Mourtos, N.J., Okamoto, N.D., \& Rhee, J. (2004). Defining, Teaching, and Assesing Problem Solving Skill. Papers presented in 7th UICEE Annual Conference on Engineering Eduction, in Mumbai, India.

Munandar, A. (2018). Pengaruh Model Pembelajaran Reciprocal Teaching Terhadap Kemampuan Berfikir Kritis Matematis pada Siswa MTS. Skripsi. Aceh: Universitas Islam Negeri ArRaniry Darussalam

Otacioğlu, S.G. (2008). Prospective Teachers' Problem Solving Skills and Self-Confidence Levels. Journal Educational Sciences: Theory \& Practice, 915-923.

O'Connell, Susan. (2000). Introduction to Problem Solving: Grades prek- 2. Porthsmouth: Heinemann.

Özreçberoğlu, N \& Çağanağa, Ç,K. (2017). Making It Count: Strategies for Improving Problem-Solving Skills in
Mathematics for Students and Teachers' Classroom Management. EURASIA Journal OF Mathematics, Science and Technology Education, 14(4), 1253-1261.

Pertiwi, F.K. (2014). Efektivitas Pembelajaran Matematika Berbasis Masalah Menggunakan Model Pembelajaran Kooperatif Think TalkWrite (TTW) dan Think-Pair-Share (TPS) Ditinjau dari Kemampuan Pemecahan Masalah Matematika dan Kepercayaan Diri SMP Negeri 1 Wonosari Skripsi. Yogyakarta:

Universitas Negeri Yogyakarta.

Polya, G. (1973). How To Solve It. New Jersey: Princeton University Press

Prastowo, Andi. (2011). Memahami Metode-Metode Penelitian: Suatu Tinjauan Teoritis dan Praktis. Yogyakarta: AR-RUZZ MEDIA

Rifa'i, Anwar. (2016). Efektivitas Model Pembelajaran Think Pair Share (TPS) dan Spontaneous Group Discussion (SGD) dengan Pendekatan Saintifik Ditinjau Dari Kemampuan Pemecahan Masalah dan Kepercayaan Diri Siswa Kelas X MIA di MAN 1 Yogyakarta. Skripsi. Yogyakarta: Universitas Negeti Yogyakarta.

Sanjaya, Wina. (2016). Strategi Pembelajaran Berorientasi Standar Proses Pendidikan. Jakarta: PRENADAMEDIA GROUP

Slameto. (2013). Belajar dan FaktorFaktor yang Mempengaruhinya. Jakarta: PT Rineka Cipta.

Slavin, Robert E. (2016). Cooperative Learning (Teori, Riset, Praktik). Bandung: Penerbit Nusa Media. 
Sugiyono. (2016). Metode Penelitian Kuantitatif Kualitatif dan Kombinasi (Mixed Methods). Bandung: Alfabeta

Suprijono. (2016). Cooperative Learning Teori \& Aplikasi PAIKEM. Yogyakarta: Pustaka Pelajar

Syah, Muhibbin. (2010). Psikologi Pendidikan Dengan Pendekatan Baru. Bandung: PT Remaja Rosdakarya Offset

Undang-Undang No.20 Tahun 2003 tentang Sistem Pendidikan Nasional

Walsh, L. N., Howard, R. G., \& Bowe, B. (2007). Phenomenographic study of students' problem solving approaches in physics. Physical Review Special Topics-Physics Education Research, 3,2 .

Wena, Made. (2011). Strategi Pembelajaran Inovatif Kontemporer. Jakarta: PT Bumi Aksara.

Yuliati, L., Riantoni, C., Mufti, N. (2018). Problem Solving Skills on Direct Current Electricity through InquiryBased Learning with PhET Simulations. International Journal of Instruction, 11, 126. 